\title{
Costs of Infection Control and Special Challenges during the Covid-19 Pandemic: Experiences in a Military Hospital ${ }^{1}$ \\ Irén KOPCSÓNÉ NÉMETH² - Márta PÉNTEK _ Zsombor ZRUBKA ${ }^{4 \odot}$
}

\begin{abstract}
Infection prevention and control (IPC) is a set of evidence-based practices of hospital epidemiology aiming to prevent and control healthcare-associated infections. The aim of the present study was two-fold. First, we estimated the costs of IPC in the Medical Centre of the Hungarian Defence Forces (MCHDF) in Hungary using a bottom-up microcosting approach. Second, we analysed how the involvement of the MCHDF in Covid-19 care changed the occurrence of multidrug-resistant infections in the hospital. Our results showed that depending on the type of ward, the daily costs of standard care ranged between 3,8098,589 HUF, while the costs of isolation were between 9,203-11,200 HUF. Daily costs were highest in the intensive care unit (ICU). Total costs per patient ranged between 20,875-78,904 HUF for standard care and 79,996-282,892 HUF for isolation with highest values in the Neonatal Intensive Care Unit (NICU). The incremental isolation cost per patient compared to standard care ranged between 20,363-158,216 HUF. When the MCHDF became a Covid-19 care centre, the incidence of introduced Clostridium difficile and multidrug resistant cases increased by nearly 200 per cent and 40 per cent, respectively. Our results can be used as basic input data for the economic evaluation of IPC strategies and highlights an important IPC aspect to be considered for the redistribution of hospital capacities during the Covid-19 pandemic.
\end{abstract}

Keywords: infection control, economics, cost, multidrug-resistant infection, Covid-19, military hospital

The authors are grateful to Professor László Gulácsi (Óbuda University) for his helpful and constructive comments during the study and on previous versions of the article. Furthermore, the authors thank the management team of the Medical Centre of the Hungarian Defence Forces for their permanent support of this study.

2 Medical Centre, Hungarian Defence Forces; Corvinus University of Budapest, Doctoral School of Business and Management; e-mail: kopne.ira@gmail.com

$3 \mathrm{PhD}$, Health Economics Research Center, University Research and Innovation Center, Óbuda University; e-mail: pentek.marta@uni-obuda.hu

$4 \quad \mathrm{PhD}$, Health Economics Research Center, University Research and Innovation Center, Óbuda University; Corvinus Institute for Advanced Studies, Corvinus University of Budapest; e-mail: zrubka.zsombor@uniobuda.hu 


\section{Introduction}

Although the invention of antibiotics has increased human life-expectancy substantially, ${ }^{5}$ their extensive use over the past decades led to the development of multidrug resistant bacteria (MDR), leading to treatment failure in potentially life-threatening infections. In addition, the use of antibiotics may result in the overgrowth of toxin-secreting Clostridium difficile (CD) bacteria potentially leading to severe diarrhoea or even death. ${ }^{6}$ One of the biggest challenges for healthcare providers today is the prevention of healthcare-associated infections (HAIs, or nosocomial infections) caused by MDR bacteria.

In countries with advanced healthcare systems, a worrying trend in the development of nosocomial infections and bacterial resistance has been recognised for decades, with increasing attention being paid to its prevention and treatment. In the last two decades, however, due to the accelerated spread of MDR bacteria, this has become an urgent compulsion everywhere. According to the report of Centers for Disease Control and Prevention (CDC) in the U.S., over 2.8 million MDR infections occur each year, and more than 35,000 people die as a result. In addition, in 2017 altogether 223,900 cases of CD occurred in the U.S. and at least 12,800 people died.7 The European Centre for Disease Prevention and Control (ECDC) reported that each year more than 3.2 million patients were infected at least once following exposure in healthcare facilities across the European Union and as a direct consequence of the infection, up to 37,000 of them died. ${ }^{8}$

Nosocomial infections can spread from infected or colonised patients to other patients and to staff. Appropriate isolation/precautions can reduce transmission if they are applied properly. Infection prevention and control (IPC) is a set of preventive practices based on scientific evidence of hospital epidemiology. IPC aims to prevent healthcare-associated infections. ${ }^{9}$ Isolation/precautions policies have several parts: hand hygiene, protective clothing, single rooms with special ventilation, environment hygiene, decontamination and sterilisation. Basic hygienic precautions (standard precautions) are recommended for all patient encounters. Transmission-based precautions (contact, droplet, airborne and mix precautions) are used for containing highly transmissible and/or epidemiologically important pathogens. ${ }^{10}$

The effectiveness of IPC has been proven in relation to various infections and healthcare settings. ${ }^{11}$ In addition to precautionary isolation, comprehensive strategic measures, such

5 MI Hutchings, AW Truman and B Wilkinson, 'Antibiotics: Past, Present and Future', Current Opinion in Microbiology 51 (2019), 72-80.

6 Gulácsi et al., 'Clostridium Difficile Infection: Epidemiology, Disease Burden and Therapy', Orvosi Hetilap 154, no 30 (2013), 1188-1193.

7 CDC, Antibiotic Resistance Threats in the United States, 2019 (Atlanta, GA: U.S. Department of Health and Human Services, 2019).

8 European Centre for Disease Prevention and Control, Economic Evaluations of Interventions to Prevent Healthcare-Associated Infections (Stockholm, 2017).

9 CDC, 'Infection Control', s. a.

10 M Mikulska, 'Infection Control and Isolation Procedures', in The EBMT Handbook, ed. by E Carreras, C Dufour, M Mohty and N Kröger (Cham: Springer, 2019), 189-195.

11 Alp et al., 'Evaluation of the Effectiveness of an Infection Control Program in Adult Intensive Care Units: A Report from a Middle-Income Country’, American Journal of Infection Control 42, no 10 (2014), 10561061 . 
as designated nursing staff and clustering patients in dedicated areas according to their infections can further enhance the effectiveness of IPC programmes. ${ }^{12}$ However, less is known about the economic aspects of implementing different IPC measures. Health economic evaluations can inform about the comparative health benefits and required investments of alternative interventions. ${ }^{13}$ The health effects of the interventions can be expressed in natural units (cost-effectiveness analysis), in quality-adjusted life years (costutility analysis) or in monetary terms (cost-benefit analysis). Costs are equally expressed in monetary terms in health economic evaluations. The analyses can be performed from different perspectives (for example, patient, hospital, insurance, healthcare system, society) and relevant cost items are included accordingly.

A systematic literature review by Tchouaket Nguemeleu et al. on economic analyses of healthcare-associated IPC interventions in medical and surgical units was performed for the period between 2000 and 2019. ${ }^{14}$ Although the overall quality of the seven included papers was moderate, results suggested that clinical best practices of IPC generated net cost savings. In Canada, cost-benefit analysis was used to evaluate the effectiveness of a regional IPC programme in preventing incident cases of selected HAIs over a 4-year period. ${ }^{15}$ The IPC programme resulted in a reduction of 19 per cent HAIs with a cost saving of 9 million Canadian dollars. The ECDC performed a literature review to assess the economic evaluations of interventions to prevent HAIs. ${ }^{16}$ Altogether, 28 evaluations were identified (hand hygiene interventions: $\mathrm{N}=4$, personal protective equipment: $\mathrm{N}=3$; screening and/or isolation and/or decolonisation interventions: $\mathrm{N}=21$ ) with considerable heterogeneity across the studies. Moreover, most of the evaluations were performed in the U.S., followed by some European countries (for example, the U.K., the Netherlands, Switzerland), hence the available evidence does not cover a Europe-wide perspective. ${ }^{17}$ Given the diversity of health status, healthcare systems, availability of technologies, current clinical practice and economic development level across Europe, the transferability of economic evaluations is limited. ${ }^{18}$ Therefore, there is a clear need for local input data on both the resource use and unit costs reflecting the real situation in that country. ${ }^{19}$

The outbreak of the Covid-19 pandemic in 2020 has brought new challenges to IPC. On the one hand, new IPC measures directly related to Covid-19 had to be taken. Guidelines

12 Fournier et al., 'Efficiency of Different Control Measures for Preventing Carbapenemase-Producing Enterobacteria and Glycopeptide-Resistant Enterococcus Faecium Outbreaks: A 6-Year Prospective Study in a French Multihospital Institution, January 2010 to December 2015', Eurosurveillance 23, no 8 (2018).

13 Drummond et al., Methods for the Economic Evaluation of Health Care Programmes (Oxford: Oxford University Press, 2005).

14 Tchouaket Nguemeleu et al., 'Economic Analysis of Healthcare-Associated Infection Prevention and Control Interventions in Medical and Surgical Units: Systematic Review Using a Discounting Approach', Journal of Hospital Infection 106, no 1 (2020), 134-154.

15 S Raschka, L Dempster and E Bryce, 'Health Economic Evaluation of an Infection Prevention and Control Program: Are Quality and Patient Safety Programs Worth the Investment?', American Journal of Infection Control 41, no 9 (2013), 773-777.

16 European Centre for Disease Prevention and Control, Economic Evaluations of Interventions.

17 Ibid.

18 Drummond et al., 'Transferability of Economic Evaluations across Jurisdictions: ISPOR Good Research Practices Task Force Report', Value in Health 12, no 4 (2009), 409-418.

19 Rennert-May et al., 'Economic Evaluations and Their Use in Infection Prevention and Control: A Narrative Review’, Antimicrobial Resistance and Infection Control 7 (2018). 
were adapted to the pandemic situation and, for instance, guidance for risk assessment of healthcare workers with potential exposure to Covid-19 were developed, recommendations on work restrictions and criteria for return to work for healthcare personnel with suspected or confirmed Covid-19 were established, as well as methods of optimising the supply of protective equipment. ${ }^{20}$ On the other hand, the excess use of antimicrobial agents during the Covid-19 pandemic increased the incidence of antimicrobial resistance. ${ }^{21}$ Moreover, we cannot ignore the effects of the extra pressure Covid-19 puts on the healthcare system. The possible temporary staff shortages on both Covid-19 and other wards, the unavoidable restructuring of care (in terms of healthcare staff and health care services) might result a reduced compliance with IPC rules, especially in the learning and adaptation phase. In contrast, many interventions (for example, elective surgeries) were postponed which may reshape in a favourable direction the actual incidence of healthcare-related infections.

In this paper two aspects of the implementation of IPC are discussed. First, we address the costs associated with IPC. We report a pilot study in which patient-level standardand transmission-based precaution activities were recorded in a large military hospital in Hungary with good IPC practice. In particular, costs were measured for those IPC activities, which are treated as overhead costs and cannot be retrieved from patients' medical records. These data can serve as a basic input for the estimation of financial demands of implementing IPC in other hospitals in Hungary. Second, through the example of the Covid-19 pandemic, we present some challenges of IPC in clinical practice. We describe how the occurrence of multidrug resistant infections changed since this same military hospital has been involved in the care of Covid-19 patients and discuss the opportunities IPC can offer to curb the wide-ranging effects of a pandemic.

\section{Empirical research in a military hospital}

\section{Current IPC practice: resource utilisation and costs}

This study was part of the research programme "Professional methodological development of the healthcare system (EFOP 1.8.0-VEKOP-17-2017-00001 project) - Change of organizational culture and patient safety culture” sub-project. The aim of this sub-project was to strengthen and integrate IPC activities into the National Health Insurance Fund financing system of Hungary. The pilot study was designed to provide basic input data for the estimation of financial needs of implementation of IPC at the hospital level. The Medical Centre of the Hungarian Defence Forces (MCHDF) has implemented IPC since 2012; therefore, it served as a suitable venue for assessing IPC costs in real-world practice.

CDC, ‘Covid-19 Infection Control Guidance’, s. a.

21 Lai et al., 'Increased Antimicrobial Resistance During the Covid-19 Pandemic', International Journal of Antimicrobial Agents 57, no 4 (2021), 106324. 


\section{Study design and patient sample}

The study was performed in a fixed 7-day time interval (from 30 March to 5 April in 2020). All patients receiving inpatient care in the Intensive Care Unit (ICU), Neonatal Intensive Care Unit (NICU), Internal Medicine (IM) and Surgical wards of the MCHDF were involved. No exclusion criteria were applied in terms of length of stay within the study period, that is, patients were both involved if they were already inpatients at the start of the study or had been admitted or discharged during the study period.

\section{Infection prevention and control activities}

Microbiological screening (laboratory tests) as well as IPC activities to detect and handle MDR and CD infections in the hospital are regulated by professional guidelines. All patients admitted into the hospital are treated following the basic standards of IPC. Depending on the transmission characteristics of the infection, patients of our study sample were stratified into four IPC groups: 1. standard care (also called standard isolation); 2. contact isolation; 3. droplet isolation; and 4. mixed isolation.

Standard care comprises routine IPC measures such as hand hygiene (based on the 5 -moment rule of the WHO), ${ }^{22}$ use of personal protective equipment (gloves, protective jacket, mask, protective glasses) and decontamination of frequently touched surfaces based on predefined HAI rules. Contact isolation comprises the same methods as standard care; however, these are applied more frequently and more extensively (for example, decontamination of frequently touched surfaces should be performed at least twice per day) based on predefined HAI rules. Droplet isolation comprises the same methods as standard care; however, the use of mask and protective gloves are obligatory for all activities. Mixed isolation comprises the techniques of both contact and droplet isolation.

\section{Measurement of resource use and costing}

To estimate the costs if IPC, a bottom-up microcosting approach was used with slight modifications. ${ }^{23}$ Data collection was performed on the individual (patient) level. All IPC activities/interventions that were performed on participants during the study period were recorded. Costs were estimated on the intervention level, that is, resource use data were multiplied by unit cost to estimate the expenditure.

In our study, only bedside IPC activities were taken into account. Activities in other hospital units than bedside (for example, operating room, laboratory) were not measured directly as these costs can be estimated based on protocols. The medical treatment related to the infections was also out of scope in this study.

WHO, Your 5 Moments for Hand Hygiene (Geneva, 2009).

Špacírová et al., 'A General Framework for Classifying Costing Methods for Economic Evaluation of Health Care', The European Journal of Health Economics 21, no 4 (2020), 529-542. 
Considering the respective IPC guidelines and legislations, for each patient by ward (IM, ICU, NICU, Surgical) and type of IPC protocol (standard care, contact, droplet, mixed isolation), resource use was recorded for the following items: antiseptic handwashing, alcohol-based hand rub, medical gloves (non-sterile), medical gloves (sterile), protective gowns, isolation gowns, protective masks, surgical masks, surface disinfection and equipment disinfection via wiping towels, textile cleaning and terminal cleaning at patient discharge.

For each patient, the number of days spent in the study and type of isolation was recorded. For cost estimation, we used mean length of stay reports of the IM, ICU, NICU and Surgical wards of the MCHDF for the entire 2019 (pre-Covid) year.

Unit costs of the materials and equipment were considered based on average Hungarian Forint (HUF) purchase price of the Hospital (MCHDF), multiplied by the average unit consumption per resource use episode (for example, mean use of alcohol-based hand rub per handwash in millilitres.) The average unit consumption per resource use episode was established from applicable WHO guidelines.

\section{Statistical analysis}

Given the small sample size and incomplete observation of the isolation episodes during the study period, we estimated costs via Monte-Carlo simulation. ${ }^{24}$ For the standard care and isolation groups, we simulated daily resource use from the sample correlation matrices, mean values and standard errors of all items via gamma distribution for cohorts of 100 thousand observations. Length of stay and the duration of isolation was also simulated via gamma distribution. For each resource item, net unit prices were calculated using the weighted mean of purchase prices in proportion with the 2020 consumption volume. We assumed a standard error equal to 10 per cent of the mean for each price item and a gamma distribution. To account for incidental variation of consumed amounts per episode, for liquid soap, alcohol-based disinfectant preparations and textile cleaning we applied a gamma distribution assuming a standard error equal to 10 per cent of the mean values. The cost of closing disinfection was treated as a fixed cost and allocated evenly across standard care as well as isolation days. Simulated costs were analysed using descriptive methods (mean and 2.5-97.5 percentile range for 95 per cent credible interval). Furthermore, we performed one-way sensitivity analysis by examining the impact of changing resource use and cost parameters by $+/-10$ per cent. We observed the changes of mean daily costs and total patient costs in both the standard care and isolation groups. The simulation and analyses were performed using Stata 16 statistical software. ${ }^{25}$

24 A Briggs, K Claxton, and M Sculpher, Decision Modelling for Health Economic Evaluation (Oxford: Oxford University Press, 2006).

25 Stata Statistical Software: Release 16, StataCorp LLC, College Station, TX. 


\section{Results}

Altogether 84 patients were involved during the 7-day study period (IM ward: $\mathrm{N}=16$; ICU: $N=32$; NICU: $N=22$; Surgical ward: $N=14$ ). Standard care was provided for 64 patients (279 days of observation) 20 patients over a total of 64 observation days were in isolation (contact isolation $\mathrm{N}=13$; droplet isolation $\mathrm{N}=1$; mixed isolation $\mathrm{N}=6$ ). Altogether 7, 7, 2 and 4 patients were observed under isolation in the IM, ICU, NICU and Surgical wards, respectively. Mean $( \pm S D)$ days of observation per patient was $4.4( \pm 2.2)$ days in the standard care and $4.0( \pm 2.8)$ days in the isolation group. Table 1 summarises the main input parameters of the cost simulation model.

Table 1: Summary of input parameters to infection control cost estimation

\begin{tabular}{|c|c|c|c|c|c|c|c|c|}
\hline & 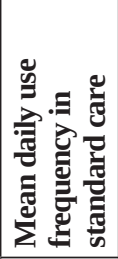 & 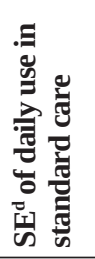 & 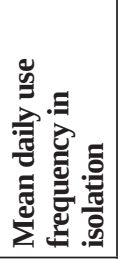 & 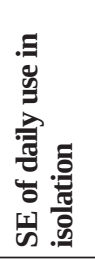 & 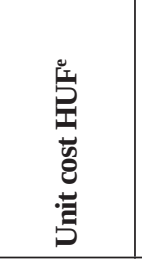 & 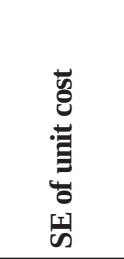 & 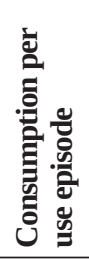 & 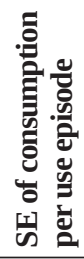 \\
\hline $\begin{array}{l}\text { Antiseptic } \\
\text { handwashing }\end{array}$ & 6.95 & 0.93 & 6.75 & 1.94 & 0.43 & 0.04 & $3 \mathrm{ml}^{\mathrm{f}}$ & 0.30 \\
\hline $\begin{array}{l}\text { Alcohol-based hand } \\
\text { rub }^{\mathrm{b}}\end{array}$ & 20.64 & 1.22 & 26.12 & 2.98 & 1.72 & 0.17 & $3 \mathrm{ml}$ & 0.30 \\
\hline $\begin{array}{l}\text { Non-sterile medical } \\
\text { gloves }^{c}\end{array}$ & 26.14 & 1.42 & 28.83 & 4.37 & 5.12 & 0.51 & $2 \mathrm{pc}^{\mathrm{g}}$ & - \\
\hline $\begin{array}{l}\text { Sterile medical } \\
\text { gloves }^{c}\end{array}$ & 0.63 & 0.12 & 2.36 & 1.82 & 35.48 & 3.55 & $2 \mathrm{pc}$ & - \\
\hline Protective gown & 1.33 & 0.22 & 4.03 & 1.36 & 143.82 & 14.38 & $1 \mathrm{pc}$ & - \\
\hline Isolation gown & 0.61 & 0.20 & 8.77 & 1.55 & 143.82 & 14.38 & $1 \mathrm{pc}$ & - \\
\hline Protective mask & 2.93 & 0.51 & 8.44 & 3.22 & 400.94 & 40.09 & $1 \mathrm{pc}$ & - \\
\hline Surgical mask & 7.42 & 0.82 & 12.70 & 1.95 & 4.30 & 0.43 & $1 \mathrm{pc}$ & - \\
\hline Surface disinfection & 1.82 & 0.18 & 2.44 & 0.83 & 21.40 & 2.14 & $1 \mathrm{pc}$ & - \\
\hline $\begin{array}{l}\text { Equipment } \\
\text { disinfection }\end{array}$ & 3.11 & 0.25 & 7.36 & 2.42 & 21.40 & 2.14 & $1 \mathrm{pc}$ & - \\
\hline Textile cleaning & 1.57 & 0.14 & 3.79 & 0.84 & 663.00 & 66.30 & $1 \mathrm{oc}^{\mathrm{h}}$ & 0.10 \\
\hline $\begin{array}{l}\text { Final disinfection } \\
\text { (IM, Surgical) }\end{array}$ & - & - & - & - & $6,800.00$ & 680.00 & 1 oc & - \\
\hline $\begin{array}{l}\text { Final disinfection } \\
\text { (ICU, NICU) }\end{array}$ & - & - & - & - & $19,800.00$ & $1,980.00$ & 1 oс & - \\
\hline
\end{tabular}

${ }^{\mathrm{a}}$ with soap, water or other antiseptic detergents; ${ }^{b}$ alcohol-based liquid or gel preparation; 'disposable; ${ }^{d}$ SE: standard error; ${ }^{\mathrm{e}}$ mean exchange rate (2020.04.16-2021.04.15) 1 EUR = 356.7 HUF; eml: millilitres, ${ }^{\mathrm{f}} \mathrm{pc}$ : piece(s), ${ }^{\mathrm{g}} \mathrm{oc}$ : occasion

Source: Compiled by the authors.

The costs of standard care and isolation by ward as well as the incremental costs of isolation are summarised in Table 2. In addition to mean values, the 95 per cent credible intervals are provided. 
Table 2: Summary of cost estimates by IPC activity and ward

\begin{tabular}{|c|c|c|c|c|c|}
\hline & & IM & ICU & NICU & Surgical \\
\hline \multirow[t]{3}{*}{$\begin{array}{l}\text { Standard } \\
\text { care }\end{array}$} & $\begin{array}{l}\text { Total daily cost } \\
\text { (HUFa); mean, } \\
\text { [95CIb] }\end{array}$ & $\begin{array}{l}3,809 \\
{[3,136-4,596]}\end{array}$ & $\begin{array}{l}8,589 \\
{[7,190-10,178]}\end{array}$ & \begin{tabular}{|l}
4,089 \\
{$[3,399-4,882]$}
\end{tabular} & $\begin{array}{l}4,539 \\
{[3,818-5,361]}\end{array}$ \\
\hline & \begin{tabular}{|l|} 
Length of stay \\
(HUF); mean, [95CI] \\
\end{tabular} & \begin{tabular}{|l|}
9.1 \\
{$[8.9-9.3]$} \\
\end{tabular} & \begin{tabular}{|l|}
3.6 \\
{$[3.1-4.1]$} \\
\end{tabular} & \begin{tabular}{|l|}
19.3 \\
{$[18.3-20.3]$} \\
\end{tabular} & $\begin{array}{l}4.6 \\
{[4.4-4.8]} \\
\end{array}$ \\
\hline & $\begin{array}{l}\text { Total cost (HUF); } \\
\text { mean, [95CI] }\end{array}$ & \begin{tabular}{|l|}
34,663 \\
{$[28,529-$} \\
$41,819]$ \\
\end{tabular} & \begin{tabular}{|l|}
30,824 \\
{$[26,159-$} \\
$35,920]$ \\
\end{tabular} & \begin{tabular}{|l|}
78,904 \\
{$[65,354-$} \\
$94,615]$ \\
\end{tabular} & $\begin{array}{l}20,875 \\
{[17,538-} \\
24,677]\end{array}$ \\
\hline \multirow[t]{3}{*}{ Isolation } & $\begin{array}{l}\text { Total daily cost } \\
\text { (HUF); mean, [95CI] }\end{array}$ & $\begin{array}{l}9,203 \\
{[5,561-14,190]}\end{array}$ & \begin{tabular}{|l}
11,200 \\
{$[7,441-16,254]$}
\end{tabular} & \begin{tabular}{|l}
9,265 \\
{$[5,614-14,270]$}
\end{tabular} & $\begin{array}{l}9,413 \\
{[5,753-14,419]}\end{array}$ \\
\hline & $\begin{array}{l}\text { Length of isolation } \\
\text { (HUF); mean, [95CI] }\end{array}$ & $\begin{array}{l}11.4 \\
{[10.6-12.2]}\end{array}$ & \begin{tabular}{|l|}
7.8 \\
{$[5.8-10.1]$}
\end{tabular} & \begin{tabular}{|l|}
30.6 \\
{$[23.9-38.1]$} \\
\end{tabular} & $\begin{array}{l}8.5 \\
{[7.3-9.8]}\end{array}$ \\
\hline & $\begin{array}{l}\text { Total cost (HUF); } \\
\text { mean, [95CI] }\end{array}$ & \begin{tabular}{|l|}
104,907 \\
{$[63,023-$} \\
$162,334]$
\end{tabular} & \begin{tabular}{|l|}
86,935 \\
{$[55,120-$} \\
$132,809]$ \\
\end{tabular} & \begin{tabular}{|l|}
282,892 \\
{$[163,214$} \\
$453,760]$ \\
\end{tabular} & $\begin{array}{l}79,996 \\
{[47,998-} \\
124,730]\end{array}$ \\
\hline \multirow[t]{2}{*}{$\begin{array}{l}\text { Isolation } \\
\text { vs standard } \\
\text { care } \\
\end{array}$} & $\begin{array}{l}\text { Incremental cost per } \\
\text { day (HUF); mean, } \\
{[95 \mathrm{CI}]}\end{array}$ & $\begin{array}{l}5,393 \\
{[5,379-5,407]}\end{array}$ & $\begin{array}{l}2,612 \\
{[2,597-2,626]}\end{array}$ & $\begin{array}{l}5,176 \\
{[5,162-5,190]}\end{array}$ & $\begin{array}{l}4,875 \\
{[4,861-4,889]}\end{array}$ \\
\hline & $\begin{array}{l}\text { Incremental cost per } \\
\text { patient (HUF); mean, } \\
{[95 \mathrm{CI}]}\end{array}$ & $\begin{array}{l}61,488 \\
{[57,109-} \\
66,016] \\
\end{array}$ & \begin{tabular}{|l|}
20,363 \\
{$[15,107-$} \\
$26,393]$
\end{tabular} & $\begin{array}{l}158,216 \\
{[123,584-} \\
197,043] \\
\end{array}$ & $\begin{array}{l}41,452 \\
{[35,471-} \\
47,857] \\
\end{array}$ \\
\hline
\end{tabular}

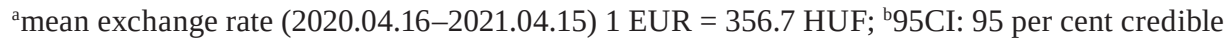
interval (2.5-97.5 percentile range of the simulated distribution)

Source: Compiled by the authors.

The results of the one-way sensitivity analyses are provided in Figure 1 . The daily costs of standard care were most sensitive to the costs of terminal cleaning and were negatively influenced by the length of stay due to the fix nature of terminal cleaning costs. Isolation costs were most sensitive to the quantity used and unit cost of protective masks, textile cleaning as well as terminal cleaning. Total costs of standard care and isolation were both most sensitive to the length of stay or length of isolation, as well as quantity and unit cost of protective masks, textile cleaning and terminal cleaning. 
A) Standard care cost per day

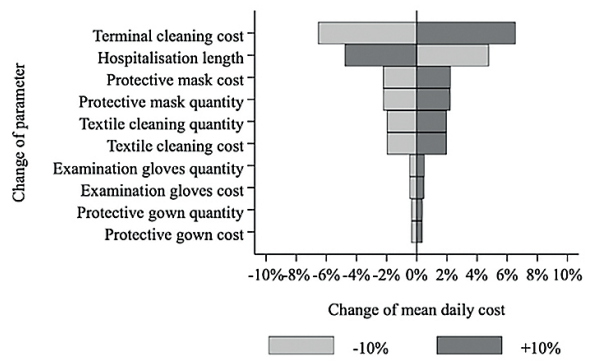

C) Standard care total cost per patient

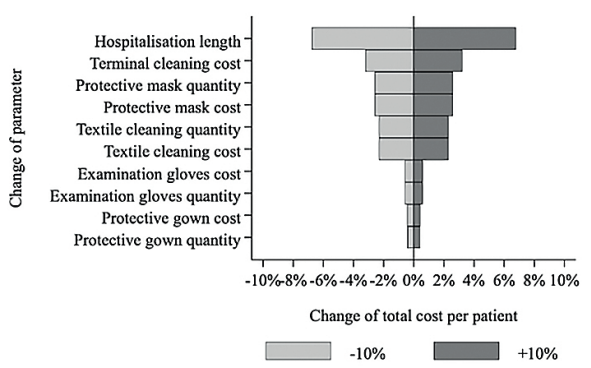

Figure 1: Results of one-way sensitivity analyses

Source: Compiled by the authors.

\section{Multidrug resistant infections during the Covid-19 pandemic}

During the Covid-19 pandemic, special infection control measures were introduced in Hungarian hospitals to prevent the spread of SARS-CoV-2. Until November 2020, the MCHDF encountered incidental Covid-19 cases, who were diagnosed during routine care, and after immediate isolation, were transferred to designated care centres. From November 2020 (Covid-care period), a designated Covid-19 care ward was established at the MCHDF, and the number of (predominantly severe) Covid-19 cases increased markedly compared to the pre-Covid-care period (Figure 2). We examined the impact of the pandemic on the occurrence of MDR and CD cases in the hospital.

\section{Methods}

Using data from the hospital's IPC surveillance system, we compared the monthly incidence of introduced (for example, acquired outside the hospital) MDR and CD cases 
per 1,000 inpatients as well as the incidence density of nosocomial (for example, acquired in the hospital) MDR and CD cases per 10,000 inpatient days between the Covid-care and pre-Covid-care periods. Only months affected by the first and second wave of the pandemic (March-June, September-December) were included for 2019 and 2020. We applied Poisson regression, with time (months) as well as well as the Covid-care period (vs pre-Covid-care) as predictors. We also analysed the association between the number of Covid-19 patients (counted in 100's) and CD/MDR incidence. If the Poisson regression was not applicable due to inadequate distribution of data or goodness of fit test results, the generalised Poisson model was applied. ${ }^{26}$

\section{Results}

The incidence of Covid patients were plotted against the incidence of introduced and nosocomial CD and MDR cases in Figure 2.

A) Introduced CD

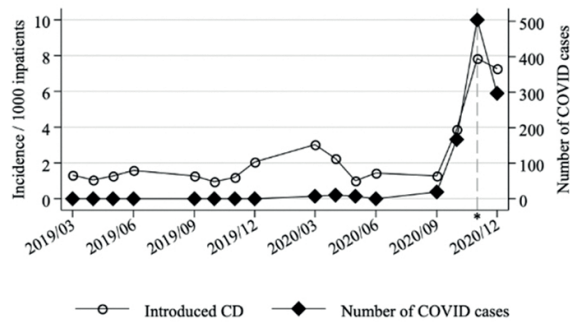

C) Nosocomial CD

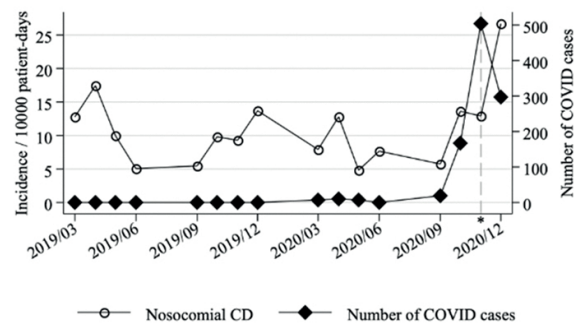

B) Introduced MDR

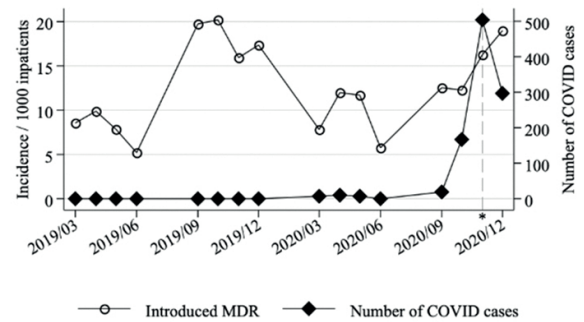

D) Nosocomial MDR

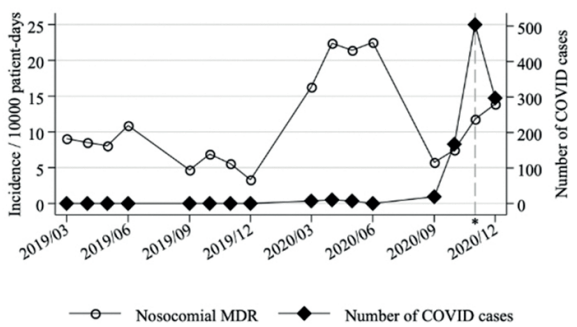

* COVID-care period starting from 2020/11

Figure 2: The incidence of Covid patients plotted against the incidence of introduced and nosocomial CD and MDR cases

Source: Compiled by the authors.

26 T Harris, Z Yang and JW Hardin, 'Modeling Underdispersed Count Data with Generalized Poisson Regression', The Stata Journal 12, no 4 (2012), 736-747. 
The incidence of introduced CD cases showed a mild increase over time, while the incidence of introduced MDR and nosocomial CD as well as MDR cases was stable over time. However, during the Covid-period, the incidence of introduced CD cases nearly tripled and the incidence of introduced MDR cases increased by nearly 40 per cent compared to the pre-Covid period. While the incidence density of nosocomial CD cases increased by over 2-fold, the change in nosocomial MDR incidence density was not significant (Table 3). The number of Covid cases showed association with the incidence of both introduced and nosocomial CD, while the association with MDR cases was not significant.

Table 3: Effect of the Covid-care period on the incidence of MDR and CD

\begin{tabular}{|c|c|c|c|c|}
\hline \multirow[b]{2}{*}{ Model } & \multicolumn{2}{|c|}{ Incidence per 1,000 patients } & \multicolumn{2}{|c|}{$\begin{array}{l}\text { Incidence density per } \\
10,000 \text { patient days }\end{array}$} \\
\hline & $\begin{array}{l}\text { Poisson } \\
\text { regression }^{\mathrm{a}}\end{array}$ & $\begin{array}{l}\text { Poisson } \\
\text { regression }^{\mathrm{a}}\end{array}$ & $\begin{array}{l}\text { Poisson } \\
\text { regression }^{\mathrm{a}}\end{array}$ & $\begin{array}{l}\text { Poisson } \\
\text { regression }^{\mathrm{a}}\end{array}$ \\
\hline Predictors & $\mathrm{CD}^{\mathrm{b}}$ introduced & MDR $^{\mathrm{c}}$ introduced & CD nosocomial & $\begin{array}{l}\text { MDR } \\
\text { nosocomial }\end{array}$ \\
\hline Covid-care period & $2.929 * * *$ & $1.394 *$ & $2.404^{*}$ & 0.811 \\
\hline Time (months) & $1.001^{*}$ & 1.000 & 1.000 & 1.001 \\
\hline $\mathrm{N}$ (observed months) & 16 & 16 & 16 & 16 \\
\hline
\end{tabular}

${ }^{\mathrm{a}}$ Coefficients are expressed as incidence rate ratios (IRR); ${ }^{\mathrm{b}} \mathrm{CD}$ : clostridium difficile; ${ }^{\mathrm{C}} \mathrm{MDR}$ : multi-drug resistant

$* \mathrm{p}<0.05 ; * * \mathrm{p}<0.01 ; * * * \mathrm{p}<0.001$

Source: Compiled by the authors.

Table 4: Association of the number of Covid patients with the incidence of MDR and CD

\begin{tabular}{|l|l|l|l|l|}
\hline & \multicolumn{2}{|c|}{ Incidence per 1,000 patients } & \multicolumn{2}{c|}{$\begin{array}{l}\text { Incidence density per } \\
10,000 \\
\text { patient days }\end{array}$} \\
\hline Model & $\begin{array}{l}\text { Poisson } \\
\text { regression }\end{array}$ & $\begin{array}{l}\text { Generalised } \\
\text { Poisson } \\
\text { regression }\end{array}$ & $\begin{array}{l}\text { beneralised } \\
\text { Poisson } \\
\text { regression }\end{array}$ & $\begin{array}{l}\text { Generalised } \\
\text { Poisson } \\
\text { regression }\end{array}$ \\
\hline Predictors & CD $^{\mathrm{b}}$ introduced & MDR $^{\mathrm{d}}$ introduced & CD nosocomial & $\begin{array}{l}\text { MDR } \\
\text { nosocomial }\end{array}$ \\
\hline $\begin{array}{l}\text { Number of Covid } \\
\text { patients, x100 }\end{array}$ & $1.306^{* * *}$ & 1.068 & $1.172^{*}$ & 0.950 \\
\hline Time (months) & $1.001^{*}$ & 1.000 & 1.000 & 1.001 \\
\hline N (observed months) & 16 & 16 & 16 & 16 \\
\hline
\end{tabular}

${ }^{\mathrm{a}}$ coefficients are expressed as incidence rate ratios (IRR); boefficients are expressed as incidence rate ratios (IRR); ${ }^{\mathrm{C}} \mathrm{CD}$ : clostridium difficile; ${ }^{\mathrm{d}} \mathrm{MDR}$ : multi-drug resistant

${ }^{*} \mathrm{p}<0.05 ;{ }^{* *} \mathrm{p}<0.01$; *** $\mathrm{p}<0.001$

Source: Compiled by the authors. 


\section{Discussion}

In this paper, we estimated the costs of infection control in the MCHDF and demonstrated special challenges of infection control concerning MDR and CD cases during the Covid19 pandemic. Depending on the type of ward, the daily costs of standard care ranged between 3,809-8,589 HUF, while the costs of isolation were between 9,203-11,200 HUF. Daily costs were the highest at the ICU, and the lowest at the IM wards. Total costs per patient ranged between 20,875-78,904 HUF for standard care and 79,996-282,892 HUF for isolation with highest values in the NICU ward due to lengthiest hospitalisation and isolation. The incremental isolation cost per patient compared to standard care ranged between 20,363-158,216 HUF.

When the MCHDF became a Covid-19 care centre, the incidence of introduced CD and MDR cases increased by nearly 200 per cent and 40 per cent, respectively. While the number of Covid-19 patients showed association with the incidence of both introduced and nosocomial CD, the MDR incidence was not associated with the Covid-19 patient count. The incidence density of nosocomial MDR cases was not affected during the first months of the Covid-care period.

ICP in hospitals is closely linked to continuous quality improvement, a systematic process of improving the quality of care and reducing costs. ICP has proven efficacy in reducing the incidence of HAIs, which not only compromise patient outcomes but are also very costly to manage. ${ }^{27}$ Although the cost-effectiveness of IPC practices has long been recognised, ${ }^{28}$ high quality costing studies are scarce. Fukuda et al. reviewed the quality and transferability of incremental costs of HAI until 2011 and found only a single study out of the included 89 papers that used microcosting and reported all input parameters at full detail. ${ }^{29}$ Precise data on IC-associated costs are extremely important as IPC policies are frequently influenced by cost-effectiveness considerations. ${ }^{30}$ Altogether, systematic reviews on the economic burden of HAIs suggest an increase of hospitalisation costs, length of stay and mortality. ${ }^{31}$ Economic evaluations of IPC are scarce in Hungary. The incremental costs of CD infections in 2012 were reported between 178,404-507,046 HUF depending on case severity and type of hospital ward..$^{32}$ In this study, isolation costs were estimated by attaching unit costs to activities prescribed by the institutional IPC protocol (and not to real world practice). Mean incremental hygienic costs per CD infection vs standard care ranged between 66,408-89,098 HUF per patient in IM, ICU and surgical wards. The study involved 151 patients. Another study from 2010 reported 35,144 HUF

27 Gulácsi et al., 'Risk-Adjusted Infection Rates in Surgery: A Model for Outcome Measurement in Hospitals Developing New Quality Improvement Programmes’, Journal of Hospital Infection 44, no 1 (2000), 43-52.

28 Arefian et al., 'Economic Evaluation of Interventions for Prevention of Hospital Acquired Infections: A Systematic Review’, PLoS One 11, no 1 (2016), e0146381.

29 H Fukuda, J Lee and Y Imanaka, 'Costs of Hospital-Acquired Infection and Transferability of the Estimates: A Systematic Review’, Infection 39, no 3 (2011), 185-199.

30 Tchouaket Nguemeleu et al., 'Economic Analysis of Healthcare-Associated Infection Prevention'.

31 Ibid.

32 Kopcsóné Németh et al., ‘A Clostridium Difficile Fertőzések Költsége Magyarországi Kórházakban’, Egészségügyi Gazdasági Szemle 51, no 2 (2013), 9-16. 
incremental costs of disinfection and protective gear in an MDR epidemic ${ }^{33}$ in a large county hospital involving five patients. The methods of cost collection were not reported. ${ }^{34}$

The strength of our costing study is that due to a well organised IPC surveillance system and regular training of staff in the MCHDF, the collected cost data reflect reasonably well the costs of following evidence-based IPC guidelines under real-life conditions and can potentially be generalised to other healthcare institutions in Hungary. However, the low sample size was a limitation of the costing study, and more data are needed to improve the precision of estimates.

The incidence density of nosocomial CD infections reached 26 per 10,000 hospital days in the Covid-care period, which is an alarmingly high number. Granata et al. reported 4.4 CDI cases per 10,000 hospital days in 8,402 hospitalised Covid patients in Italy, with inferior outcomes compared to the CD negative population. Sandhu et al. reported the increase of CD incidence density from 3.3 to 3.6 per 10,000 patient days during the first months of the pandemic (March-April 2020 vs January-February 2020). However, while the increased incidence of MDR infections has also been reported in connection with Covid patients, ${ }^{35}$ their incidence did not change in the MCHDF. A strength of our analysis is that the association of both introduced and nosocomial CD infections with the Covid19 pandemic could be recognised early from the IPC surveillance data. However, data was not available to assess the clinical impact of CD infection in the outcomes of patients hospitalised due to severe Covid-19 symptoms. Also, more data are needed to understand the association of the Covid-19 pandemic with the risk of MDR infections. In addition to tradition hospital epidemiology methods, there are HAI simulation frameworks available which can be useful for in-depth analysis of MDR spread dynamics. ${ }^{36}$

\section{Conclusions}

Implementation and maintenance of IPC in a hospital environment requires extra financial investment. Results of our small experimental study suggest that both the volume and structure of IPC-related costs vary substantially across different wards, being the highest in ICU unites per day and NICU units per patient. This implies that financial needs of IPC may vary significantly from hospital to hospital depending on their profile. Involvement of a hospital in Covid-19 care seems to significantly increase the incidence of admission of patients with previously acquired MDR bacteria or CD. This effect should be considered not only by the hospital IPC surveillance system but also for the reorganisation of hospital capacities and budget planning during the pandemic. Further studies are encouraged to assess the generalisability of our results to other settings in the region.

33 Granata et al., 'The Burden of Clostridioides Difficile Infection During the Covid-19 Pandemic: A Retrospective Case-Control Study in Italian Hospitals (CloVid)', Journal of Clinical Medicine 9, no 12 (2020), 3855.

34 M Knausz, G Kaproncai and F Rozgonyi, 'Cost/Benefit Calculations of Meticillin-Resistant Staphylococcus Aureus Screening Methods and Their Practical Importance’, Orvosi Hetilap 151, no 22 (2010), 893-898.

35 Lai et al., 'Increased Antimicrobial Resistance'.

36 R Pethes, T Ferenci and L Kovács, 'Infectious Hospital Agents: A Hai Spreading Simulation Framework', Acta Polytechnica Hungarica 14, no 1 (2017), 95-110. 


\section{References}

Alp, E et al., 'Evaluation of the Effectiveness of an Infection Control Program in Adult Intensive Care Units: A Report from a Middle-Income Country'. American Journal of Infection Control 42, no 10 (2014), 1056-1061. Online: https://doi.org/10.1016/j.ajic.2014.06.015

Arefian, $\mathrm{H}$ et al., 'Economic Evaluation of Interventions for Prevention of Hospital Acquired Infections: A Systematic Review’. PLoS One 11, no 1 (2016), e0146381. Online: https:// doi.org/10.1371/journal.pone.0146381

Briggs, A, K Claxton and M Sculpher, Decision Modelling for Health Economic Evaluation. Oxford: Oxford University Press, 2006. Online: https://doi.org/10.1093/ije/dym062

CDC, Antibiotic Resistance Threats in the United States, 2019. Atlanta, GA: U.S. Department of Health and Human Services, 2019. Online: https://doi.org/10.15620/cdc:82532

CDC, ‘Covid-19 Infection Control Guidance’, s. a.

CDC, 'Infection Control', s. a. Online: www.cdc.gov/infectioncontrol/index.html

Craig, D et al., Cost-Effectiveness Interventions to Prevent and Control Healthcare-Associated Infections. Centre for Reviews and Dissemination, University of York, 2012. Online: https://doi.org/10.2900/4617

Drummond, M et al., Methods for the Economic Evaluation of Health Care Programmes. Oxford: Oxford University Press, 2005.

Drummond, $\mathrm{M}$ et al., 'Transferability of Economic Evaluations across Jurisdictions: ISPOR Good Research Practices Task Force Report'. Value in Health 12, no 4 (2009), 409-418. Online: https://doi.org/10.1111/j.1524-4733.2008.00489.x

European Centre for Disease Prevention and Control, Economic Evaluations of Interventions to Prevent Healthcare-Associated Infections. Stockholm, 2017.

Fournier, S et al., 'Efficiency of Different Control Measures for Preventing CarbapenemaseProducing Enterobacteria and Glycopeptide-Resistant Enterococcus Faecium Outbreaks: A 6-Year Prospective Study in a French Multihospital Institution, January 2010 to December 2015'. Eurosurveillance 23, no 8 (2018). Online: https://doi.org/10.2807/15607917.ES.2018.23.8.17-00078

Fukuda, H, J Lee and Y Imanaka, 'Costs of Hospital-Acquired Infection and Transferability of the Estimates: A Systematic Review’. Infection 39, no 3 (2011), 185-199. Online: https:// doi.org/10.1007/s15010-011-0095-7

Granata, G et al., 'The Burden of Clostridioides Difficile Infection During the Covid-19 Pandemic: A Retrospective Case-Control Study in Italian Hospitals (CloVid)'. Journal of Clinical Medicine 9, no 12 (2020). Online: https://doi.org/10.3390/jcm9123855

Gulácsi, L et al., 'Risk-Adjusted Infection Rates in Surgery: A Model for Outcome Measurement in Hospitals Developing New Quality Improvement Programmes’. Journal of Hospital Infection 44, no 1 (2000), 43-52. Online: DOI: https://doi.org/10.1053/jhin.1999.0655

Gulácsi, L, Minőségfejlesztés az egészségügyben; surveillance a sebészeti és intenzív betegellátó osztályokon, valamint gyermek intenzív és perinatális intenzív centrumokban. $\mathrm{PhD}$ thesis, Budapest: Semmelweis University, 2002.

Gulácsi, L et al., 'Clostridium Difficile Infection: Epidemiology, Disease Burden and Therapy’. Orvosi Hetilap 154, no 30 (2013), 1188-1193. Online: https://doi.org/10.1556/ ОH.2013.29674 
Haley, RW, 'Preliminary Cost-Benefit Analysis of Hospital Infection Control Programs (the SENIC Project)', in Proven and Unproven Methods in Hospital Infection Control: Proceedings of an International Workshop at Baiersbronn, September 24-25, 1977. New York: Gustav Fischer Verlag, 1978, 93-95.

Haley, RW, 'The "Hospital Epidemiologist” in U.S. Hospitals, 1976-1977: A Description of the Head of the Infection Surveillance and Control Program. Report from the SENIC Project'. Infection Control and Hospital Epidemiology 1, no 1 (1980), 21-32. Online: https://doi. org/10.1017/S019594170005236X

Harris, T, Z Yang and JW Hardin, 'Modeling Underdispersed Count Data with Generalized Poisson Regression’. The Stata Journal 12, no 4 (2012), 736-747. Online: https://doi. org/10.1177/1536867X1201200412

Hughes, JM, 'Study on the Efficacy of Nosocomial Infection Control (SENIC Project): Results and Implications for the Future’. Chemotherapy 34, no 6 (1988), 553-561. Online: https:// doi.org/10.1159/000238624

Huskins, WC et al., 'Hospital Infection Prevention and Control: A Model for Improving the Quality of Hospital Care in Low- and Middle-Income Countries'. Infection Control and Hospital Epidemiology 19, no 2 (1998), 125-135. Online: https://doi. org/10.2307/30142003

Hutchings, MI, AW Truman and B Wilkinson, 'Antibiotics: Past, Present and Future’. Current Opinion in Microbiology 51 (2019), 72-80. Online: https://doi.org/10.1016/j. mib.2019.10.008

Knausz, M, G Kaproncai and F Rozgonyi, 'Cost/Benefit Calculations of Meticillin-Resistant Staphylococcus Aureus Screening Methods and Their Practical Importance’. Orvosi Hetilap 151, no 22 (2010), 893-898. Online: https://doi.org/10.1556/oh.2010.28869

Kopcsóné Németh, I et al., ‘A Clostridium Difficile Fertőzések Költsége Magyarországi Kórházakban’. Egészségügyi Gazdasági Szemle 51, no 2 (2013), 9-16.

Lai, CC et al., 'Increased Antimicrobial Resistance During the Covid-19 Pandemic'. International Journal of Antimicrobial Agents 57, no 4 (2021), 106324. Online: https://doi. org/10.1016/j.ijantimicag.2021.106324

Mikulska, M, 'Infection Control and Isolation Procedures', in The EBMT Handbook, ed. by E Carreras, C Dufour, M Mohty and N Kröger. Cham: Springer, 2019, 189-195. Online: https://doi.org/10.1007/978-3-030-02278-5_27

Mullish, BH and HR Williams, 'Clostridium Difficile Infection and Antibiotic-Associated Diarrhoea’. Clinical Medicine 18, no 3 (2018), 237-241. Online: https://doi.org/10.7861/ clinmedicine.18-3-237

Pethes, R, T Ferenci and L Kovács, 'Infectious Hospital Agents: A Hai Spreading Simulation Framework’. Acta Polytechnica Hungarica 14, no 1 (2017), 95-110. Online: https://doi. org/10.12700/APH.14.1.2017.1.7

Raschka, S, L Dempster and E Bryce, 'Health Economic Evaluation of an Infection Prevention and Control Program: Are Quality and Patient Safety Programs Worth the Investment?' American Journal of Infection Control 41, no 9 (2013), 773-777. Online: https://doi. org/10.1016/j.ajic.2012.10.026 
Irén KOPCSÓNÉ NÉMETH - Márta PÉNTEK - Zsombor ZRUBKA: Costs of Infection Control...

Rennert-May, E et al., 'Economic Evaluations and Their Use in Infection Prevention and

Control: A Narrative Review'. Antimicrobial Resistance and Infection Control 7 (2018).

Online: https://doi.org/10.1186/s13756-018-0327-z

Stata Statistical Software: Release 16, StataCorp LLC, College Station, TX.

Špacírová, Z et al., 'A General Framework for Classifying Costing Methods for Economic

Evaluation of Health Care'. The European Journal of Health Economics 21, no 4 (2020), 529-542. Online: https://doi.org/10.1007/s10198-019-01157-9

Tchouaket Nguemeleu, E et al., 'Economic Analysis of Healthcare-Associated Infection

Prevention and Control Interventions in Medical and Surgical Units: Systematic

Review Using a Discounting Approach’. Journal of Hospital Infection 106, no 1 (2020),

134-154. Online: https://doi.org/10.1016/j.jhin.2020.07.004

WHO, Your 5 Moments for Hand Hygiene. Geneva, 2009. 